\title{
PENGARUH PEMBERIAN SUSU BEKATUL TERHADAP KONSENTRASI KOLESTEROL DAN TRIGLISERIDAPADA TIKUS PUTIH WISTAR DIABETES
}

\author{
The Effect of Rice Bran Milk on Concentration of Cholesterol and Trglyserides \\ in Diabeticwhite Wistar Rats
}

\author{
Husnul Khatimah $^{1}$, Saifuddin Sirajuddin ${ }^{2}$, Zainal $^{3}$ \\ ${ }^{1,2}$ Bagian Gizi, Fakultas Kesehatan Masyarakat, Universitas Hasanuddin, Makassar \\ ${ }^{3}$ Bagian Teknologi Pangan, Fakultas Pertanian, Universitas Hasanuddin, Makassar \\ (husnulkhatimah5793@gmail.com, 085240877 336)
}

\begin{abstract}
ABSTRAK
Pada penderita diabetes terjadi peningkatan asam lemak bebas dalam darah dan meningkatkan konsetrasi koleserol dan trigliserida, kondisi ini disebut diabetes displidemia. Penelitian ini bertujuan untuk melihat pengaruh pemberian susu bekatul terhadap konsetrasi kolesterol dan trigliserida pada tikus putih wistar diabetes. Dilaksanakan tanggal 15 Mei - 15 Agustus 2018. Penelitian eksperimen pre-post test with control design. Subjek dua puluh ekor tikus putih wistar yang dibuat diabetes dengan menyuntikkan aloksan $140 \mathrm{mg} / \mathrm{kg}$. Setelah dinyatakan diabetes tikus lalu dibagi menjadi empat kelompok, yakni kelompok 1 (kontrol negatif), kelompok 2 (kontrol positif), kelompok 3 (susu bekatul $0,54 \mathrm{~g} / 200 \mathrm{gr}$ ) dan kelompok 4 (susu bekatul 1,08g/200gr). Intervensi diberikan selama empat belas hari. Analisis data yang digunakan untuk uji sebelum dan sesudah adalah uji T-berpasangan dan untuk uji beda kelompok digunakan uji Oneway-ANOVA. Hasil penelitian menunjukkan bahwa tidak terdapat perbedaan bermakna pada konsetrasi kolesterol dan trigliserida pada keempat kelompok. Tapi bila dilihat dari perubahan sebelum dan setelah intervensi menunjukkan bahwa kelompok 4 (susu bekatul 1,08g/200gr) terjadi penurunan konsetrasi kolesterol dan pada kelompok 3 (susu bekatul $0,54 \mathrm{~g} / 200 \mathrm{gr}$ ) terjadi penurunan trigliserida lebih baik jika dibandingkan kelompok 1 (kontrol negatif) dan kelompok 2 (kontrol positif). Disimpulkan bahwa pemberian susu bekatul dapat menurunkan konsetrasi kolesterol dan trigliserida pada tikus putih wistar diabetes.
\end{abstract}

Kata Kunci : Susu Bekatul, Kolesterol, Trigliserida, Tikus, Diabetes

\section{ABSTRACT}

In diabetics there is usually an increase in free fatty acids in the blood and increases the concentration of cholecerols and triglycerides, this condition is called diabetes dyshidemia. This study aimed to find out at the effect of bran milk treatment on the changes of the concetration of cholesterol and triglycerides in diabetetic white wistar rats. Conducted on May 15 until 15 August 2018. Experimental research pre-post test with control design. Subjects of twenty wistar white rats were made diabetic by injecting alloxan 140mg / $\mathrm{kg}$. After being declared diabetic, the rats were divided into four groups, namely group 1 (negative control), group 2 (positive control), group 3 (bran milk $0.54 \mathrm{~g} / 200 \mathrm{gr}$ ) and group 4 (bran milk $1.08 \mathrm{~g} / 200 \mathrm{gr}$ ). The intervention was given for fourteen days. The data analysis used the paired T-test to test the subject before and afterthe treatment and the OneWay ANOVA test was used to test the difference between the groups. The research results indicated that the treatment with bran milk there were no significant differences in cholesterol and triglyceride concentrations in the four groups. But when viewed from changes before and after the intervention showed that group 4 (bran milk 1.08g / 200gr) decreased cholesterol concentration and in group 3 (bran milk 0.54g / 200gr) a decrease in triglycerides was better than group 1 (control negative) and group 2 (positive control). It was concluded that the administration of bran milk can reduce the concentration of cholesterol and triglycerides in wistar diabetic white rats.

Keywords : Bran milk, Cholesterol, Triglycerides, Rats, Diabetic 


\section{PENDAHULUAN}

Diabetes melitus (DM) merupakan penyakit gangguan metabolik menahun dikarenakan pankreas tidak memproduksi cukup insulin atau tubuh yang tidak dapat menggunakan insulin yang diproduksi secara efektif ${ }^{(1)}$. Pada Tahun 2015 sebanyak 415 juta orang dewasa menderita diabetes, terjadi kenaikan 4 kali lipat dari 108 juta di tahun 1980an. Pada Tahun 2040 diperkirakan jumlahnya akan menjadi 642 juta $^{(2)}$. Pada Tahun 2015, Indonesia menempati peringkat ke-7 dunia dimana Prevalensi orang dengan diabetes di Indonesia menurut Riskesdas 2007 menunjukkan kecenderungan meningkat yaitu dari $5,7 \%^{(3)}$ menjadi 6,9\% pada Riskesdas $2013^{(4)}$.

Pada penderita diabetes mellitus akibat kondisi hiperglikemia biasanya juga terjadi peningkatan asam lemak bebas dalam darah dan kadar asam lemak bebas sejalan dengan naik turunnya kadar glukosa dalam darah. Kekurangan hormon insulin pada penderita diabetes mellitus mengakibatkan kelebihan kadar glukosa dalam darah. Hal tersebut juga mempengaruhi metabolisme lemak di dalam tubuh. Akibat berkurangnya hormon insulin maka akan terjadi peningkatan mobilisasi lemak dari daerah penyimpanan lemak, sehingga menyebabkan terjadinya peningkatan katabolisme lemak yang disertai deposisi lemak pada dinding pembuluh darah yang mengakibatkan timbulnya gejala aterosklerosis. Kondisi ini sering disebut diabetes dislipidemia ${ }^{(5)}$.
Pengobatan diabetes melitus dan dislipedemia telah menghabiskan dana yang sangat besar tiap tahunnya. Dengan makin banyaknya obat paten untuk penderita, biaya pengobatan pun semakin mahal dan tidak terjangkau terutama bagi penderita di negaranegara berkembang seperti Indonesia. Selain harganya mahal, penggunaan obat sintetik dalam jangka panjang dapat menimbulkan efek samping. Obat tradisional merupakan salah satu alternatif dalam pengobatan karena efek sampingnya dianggap lebih kecil dan harganya lebih murah dibandingkan obat modern ${ }^{(5)}$.

Salah satu bahan tradisional yang dapat digunakan sebagai obat diabetes melitus dan displidemia adalah bekatul. Bekatul merupakan sumber serat pangan (dietary fiber) yang sangat baik untuk memperlancar saluran pencernaan. Selain itu, kehadiran serat pangan juga berpengaruh terhadap penurunan kadar kolestrol darah dan pengontrol glukosa darah $^{(6)}$. Tujuan penelitin ini adalah untuk mengetahui pengaruh susu bekatul terhadap konsetrassi kolesterol dan trigliserida pada tikus putih wistar diabetes.

\section{METODE PENELITIAN}

Penelitian ini merupakan penelitian eksperimen murni atau true experiment dengan rancangan pre-post test with control group design. Penelitian ini dilakukan pada bulan 15 Mei 2018 sampai dengan bulan Agustus 2018. Pembuatan susu bekatul dilakukan di Laboratorium Kuliner Gizi Fakultas Kesehatan Masyarakat Universitas Hasanuddin dan 
Laboratorium Kuliner Poltekkes Makassar. Sementara yang terkait adaptasi dan perlakuan hewan coba dilaksanakan di Laboratorium Biofarmasi Universitas Hasanuddin. Adapun pemeriksaan konsentrasi kolesterol total dan trigliserida hewan coba dilakukan di Balai Besar Laboratorium Kesehatan Makassar. Sampel dalam penelitian ini adalah tikus (Rattus Norvegicus) Wistar jenis kelamin jantan berumur 8-12 minggu dengan bobot badan 180-250 gram (bobot badan dewasa). Sampel yang digunakan diambil secara acak dari populasi terjangkau. Besar sampel tiap kelompok perlakuan minimal 5 ekor, sesuai besar sampel tiap kelompok menurut $\mathrm{WHO}^{(7)}$.

Alat yang digunakan dalam penelitian ini antara lain: Ayakan 80 mest, gas, kompor, wajan, irus, loyang, timbangan digital, oven, kandang tikus, nippel, sonde oral, spoit $1 \mathrm{cc}$, spoit 3 cc, gelas ukur, labu ukur, batang pengaduk, sarung tangan, gunting, tabung darah beku, dry ice, cool box. Bahan yang digunakan: aloksan, glibenklamid, susu bekatul 30 gram, susu bekatul 60 gram. Analisis data yang digunakan untuk uji sebelum dan sesudah adalah uji T-berpasangan dan untuk uji beda kelompok digunakan uji Oneway-ANOVA.

\section{HASIL}

Setelah hewan coba melalui masa pemeliharaan dan adaptasi selama 1 bulan, maka setelah dinyatakan diabetes, diukur kolesterol dan trigliseridanya sebelum (pre). Kemudian setelah perlakuan pada tiap kelompok selama 14 hari kembali mengukur konsetrasi kolesterol dan trigliserida hewan coba sebagai pengukuran sesudah (post). Pengukuran konsetrasi kolesterol dan trigliserida.

\section{Tabel 1. Hasil Uji Beda Konsetrasi Kolesterol Pada Penelitian Pengaruh Susu Bekatul Terhadap Konsetrasi Kolesterol Pada Tikus Wistar Diabetes Tahun 2018}

\begin{tabular}{ccccc}
\hline \multirow{2}{*}{ Kelompok } & $\begin{array}{c}\text { Konsentrasi Kolesterol } \\
\text { Pre } \\
\text { mean }\end{array}$ & $\begin{array}{c}\text { Post } \\
\text { mean }\end{array}$ & $\Delta$ Mean & p-value \\
\hline 1 (kontrol -) & 48,40 & 63,80 & $-15,40$ & $0,019 *$ \\
2 (kontrol +) & 52,40 & 62,80 & $-10,40$ & $0,264 *$ \\
3 (SB 30 gr) & 65,80 & 73,00 & $-7,20$ & $0,132 *$ \\
4 (SB 60 gr) & 59,60 & 54,80 & 4,80 & $0,516 *$ \\
p-value & $0,035 * *$ & $0,197 * *$ & & $0,140 * *$ \\
\hline
\end{tabular}

Sumber: Data Primer, 2018

*Uji t berpasangan

** Uji one way anova

Tabel diatas menunjukkan berdasarkan hasil uji ANOVA, tidak terdapat perbedaan yang signifikan antar kelompok pada kondisi setelah perlakuan dimana tidak mengalami perbedaan yang nyata. Hasil Uji paired T-Test menunjukan bahwa kelompok yang mengalami perbedaan yang signifikan pada kondisi sebelum dan sesudah perlakuan terjadi pada kelompok $1 \quad(\mathrm{p}=0,019<0,05) \quad$ merupakan kontrol negatif namun perbedaan yang terjadi pada kelompok 1 mengarah pada peningkatan konsentrasi kolesterol total. Keadaan ini berbanding terbalik dengan kelompok 4 $(\mathrm{p}=0,516>0,05)$ yang diberikan susu bekatul 60 gram dimana terjadi penurunan konsetrasi kolesterol setelah diberikan perlakuan walaupun tidak menunjukkan perbedaan yang signifikan. 
Tabel 2. Hasil Uji Beda Konsetrasi Trigliserida Pada Penelitian Pengaruh Susu Bekatul Terhadap Konsetrasi Trigliserida Pada Tikus Wistar Diabetes Tahun 2018

\begin{tabular}{ccccc}
\hline & \multicolumn{2}{c}{ Konsentrasi } & & \\
Krigliserida & & & \\
& Pre & Post & Mean & p-value \\
& mean & mean & & \\
\hline 1 (kontrol -) & 66,00 & 60,40 & 5,60 & $0,584^{*}$ \\
2 (kontrol +) & $\mathbf{1 0 0 , 0 0}$ & $\mathbf{6 8 , 0 0}$ & $\mathbf{3 2 , 0 0}$ & $\mathbf{0 , 3 6 1 *}$ \\
3 (SB 30 gr) & 154,40 & 90,40 & 64,00 & $0,116^{*}$ \\
4 (SB 60 gr) & 98,20 & 69,80 & 28,40 & $0,141^{*}$ \\
p-value & $0,074^{* *}$ & $0,261^{* *}$ & & $0,419^{* *}$ \\
\hline
\end{tabular}

Sumber: Data Primer, 2018

*Uji t berpasangan

** Uji one way anova

Tabel 2 menunjukkan dengan uji ANOVA, tidak terdapat perbedaan yang signifikan antar kelompok pada kondisi setelah perlakuan antar kelompok dimana tidak mengalami perbedaan yang nyata. Hasil Uji paired T-Test menunjukan bahwa semua kelompok dalam penelitian ini tidak terjadi perbedaan yang signifikan antara kondisi sebelum dan sesudah perlakuan. Kelompok 3 yang diberi susu 30 gram mengalami penurunan yang paling besar dibanding dengan kelompok lain namun tidak signifikan $(\mathrm{p}=0,116>0,05)$. Penurunan sedikit ditunjukkan oleh kelompok 1 yang merupakan kelompok kontrol negatif $(\mathrm{p}=0,584>0,05)$

\section{PEMBAHASAN}

Hasil penelitian menunjukkan bahwa semua tikus mengalmai diabetes setelah di induksi aloksan tapi konsetrasi kolesterol dan trigliserida masih dalam batas normal. Diantara keempat kelompok tersebut, kelompok 1 mengalami peningkatan konsetrasi kolesterol paling tinggi yaitu $31,8 \%$ bila dibandingkan dengan kelompok 3 yang mengalami peningkatan kosentrasi kolesterol sebesar $10,9 \%$ dan kelompok 4 yang mengalami penurunan konsetrasi kolesterol sebesar $8,0 \%$, serta memiliki perbedaan bermakna dengan nilai signifikansi 0,019 $(\mathrm{p}<0,05)$ yang diuji menggunakan paired t-test. Hal ini menunjukkan bahwa kelompok perlakuan susu bekatul 30 gram dan 60 gram berhasil memberikan efek penghambatan terhadap peningkatan konsetrasi kolesterol total dalam darah. Pada kelompok 3 yang merupakan perlakuan susu bekatul 30 gram sedikit meningkat pada saat setelah diberikan perlakuan, peneliti menduga hal ini dapat disebabkan oleh komposisi pada susu bekatul yang digunakan mengandung komposisi lain yang memiliki kerja antagonis serta komposisi bekatul tidak terlalu dominan sehingga efek penurunan konsetrasi kolesterol tidak tercapai maksimal. Hasil penelitian ini sejalan dengan penelitian yang dilakukan oleh Takakori et $a l^{(8)}$ dimana konsetrasi kolesterol yang diberikan intervensi bekatul mengalami penurunan meskipun hasilnya tidak signifikan, subyek penelitiannya adalah pasien diabetes melitus tipe 2 yang berjumlah 60 orang yang terdiri dari kelompok intervensi 30 orang dan kelompok kontrol 30 orang. Kelompok intervensi diberi bekatul sebanyak 10 gram yang dikonsumsi 2 kali sehari yaitu pada saat pagi dan sore hari sebelum tidur selama 30 hari sedangkan pada kelompok kontrol hanya diberi placebo. Hasil penelitian menunjukkan terjadi penurunan konsetrasi kolesterol total meskipun hasilnya tidak signifikan. 
Hasil penelitian menujukkan bahwa semua kelompok baik kelompok kontrol maupun perlakuan mengalami penurunan konsetrasi trigliserida. Kelompok 1 yang merupakan kontrol negatif terjadi penurunan konsetrasi trigliserida sebesar $8,4 \%$ dan kelompok 2 yang merupakan kontrol positif juga terjadi penurunan konsetrasi trigliserida sebesar $32 \%$. Hal yang sama juga ditunjukkan pada kelompok perlakuan yaitu kelompok 3 dan kelompok 4 dimana terjadi penurunan konsetrasi trigliserida masing masing sebesar $41,4 \%$ dan $28,9 \%$ secara statistik tidak ada pengaruh yang signifikan. Dapat dilihat bahwa penurunaan konsetrasi trigliserida yang paling kecil pada kelompok 1 karena kelompok ini tidak diberi perlakuan apapun selain itu penurunan konsetrasi trigliserida paling besar terjadi pada kelompok 3 yang diberikan susu bekatu 30 gram. Hasil ini sejalan dengan penelitian yang dilakukan oleh Soplantila ${ }^{(9)}$ yang membuktikan bahwa intervesi berupa pemberian bekatul sebanyak 30 gram selama 14 hari mampu menurunkan konsetrasi trigliserida pada tikus wistar yang diinduksi pakan tinggi kolesterol.

\section{KESIMPULAN DAN SARAN}

Kesimpulan dari penelitian ini adalah tidak ada pengauh pemberian susu bekatul terhadap konsetrasi kolesterol dan trigliserida pada tikus putih wistar diabetes.

\section{DAFTAR PUSTAKA}

1. Kemenkes RI. Situasi dan Analisis Diabetes. Pusat Data dan Informasi Kementerian Kesehatan RI. 2014. p. 2.
2. Internasional Diabetes Federation. No Title. IDF Diabetes Atlas. 2015; Seventh Ed.

3. Kemenkes RI. Riset Kesehatan Dasar 2007. 2007.

4. Kemenkes RI. Riset Kesehatan Dasar 2013. 2013.

5. Nugroho CA. Christianto Adhy Nugroho Pengaruh Ekstrak Rosela ( Hibiscus Sabdariffa ) terhadap Kadar Trigliserida Tikus Putih Diabetes. 2012;269-80.

6. Auliana R. Manfaat Bekatul dan Kandungan Gizinya [Internet]. 2011. p. 111. Available from: http://staffnew.uny.ac.id/upload/132048525 /pengabdian/manfaat-bekatul-dankandungan-gizinya.pdf

7. World Health Organization. General Guidelines for Methodologies on Research and Evaluation of Traditional Medicine. WHO-Geneva. 2000;1:1-74.

8. Tazakori, Z; Dehghan, M.H.; Zare, M.; Foladi N. MR. Effect of rice Bran On Blood Glucose And Serum Lipid Paramenters In Diabetes II Patients. J Biol Sci [Internet]. 2007;2(3):252-255. Available from: https://www.medwelljournals.com/abstract/ ?doi=rjbsci.2007.252.255

9. Soplantila A. Pengaruh Pemberian BEkatul Terhadap HDL, LDL dan Trigliserida Pada Tikus (Rattus Norvegicus) Wistar Dengan Pakan Tinggi Kolesterol [Internet]. Universitas Hasanuddin; 2016. Available from: https://repository.unhas.ac.id/digilib/gdl.ph p? $\bmod =$ browse $\&$ p $=$ read $\& i d=--$ annafsopla24495\&PHPSESSID=ea51c46d4057ddb53 7225d694bdf5e16 